Tjalling C. Koopmans Research Institute Thlligh Aoopman

Discussion Paper Series nr: 11-03

\title{
Entrepreneurship, Innovation and Institutions
}

Erik Stam

Bart Nooteboom 


\title{
Tjalling C. Koopmans Research Institute Utrecht School of Economics \\ Utrecht University
}

Janskerkhof 12

3512 BL Utrecht

The Netherlands

telephone $\quad+31302539800$

fax +31302537373

website www.koopmansinstitute.uu.nl

The Tjalling C. Koopmans Institute is the research institute and research school of Utrecht School of Economics.

It was founded in 2003, and named after Professor Tjalling C. Koopmans, Dutch-born Nobel Prize laureate in economics of 1975.

In the discussion papers series the Koopmans Institute publishes results of ongoing research for early dissemination of research results, and to enhance discussion with colleagues.

Please send any comments and suggestions on the Koopmans institute, or this series to J.M.vanDort@uu.nl

ontwerp voorblad: WRIK Utrecht

\author{
How to reach the authors \\ Please direct all correspondence to the first author. \\ Erik Stam \\ Utrecht University \\ Utrecht School of Economics \\ Janskerkhof 12 \\ 3512 BL Utrecht \\ The Netherlands. \\ E-mail: e.stam@uu.nl \\ Scientific Council for Government Policy \\ The Netherlands \\ Bart Nooteboom \\ Tilburg University \\ Faculty of Economics and Business Administration \\ PO Box 90153 \\ 5000 LE Tilburg \\ E-mail: B.Nooteboom@uvt.nl
}


Utrecht School of Economics

Tjalling C. Koopmans Research Institute

Discussion Paper Series 11-03

\title{
Entrepreneurship, Innovation and Institutions
}

\author{
Erik Stama \\ Bart Nooteboomb \\ aUtrecht School of Economics \\ Utrecht University \\ Scientific Council for Government Policy \\ The Netherlands \\ ${ }^{\mathrm{b}}$ Faculty of Economics and Business Administration \\ Tilburg University \\ February 2010
}

\begin{abstract}
This paper discusses the nature of entrepreneurship and its relation to innovation along a cycle in which exploration and exploration follow upon each other. We place the roles of entrepreneurship in innovation policy within this cycle of innovation. Different types of innovation along the cycle of innovation are realized with different forms of entrepreneurship, which are constrained or enabled by different legal institutions. One of the key roles of governments is to design, change or destruct institutions in order to improve societal welfare. The question is what governments should do in the context of innovation policy. Here, social scientists can make a contribution by providing insight into what entrepreneurship and innovation is (theories about these phenomena), and how institutions affect them in reality (empirical evidence about their effects). This requires social scientists to be engaged scholars and to provide new policy options as an honest broker between the academic world and the policy world. The key question of this paper is: How can policy best enable innovation based entrepreneurship? The answer is derived from looking at both theoretical tenets and empirical evidence using an institutional design perspective, which aims at providing arguments for the design, change and/or destruction of institutions, given the goals of the governments. We provide an overview of some (empirically tests of) institutions that enable or restrain particular types of entrepreneurship. Examples of these institutions are intellectual property rights and the Small Business Innovation Research program, employment protection, and non-compete covenants.
\end{abstract}

Keywords: entrepreneurship, innovation, institutions, innovation policy

JEL classification: E61, G38, H57, K29, L26, L53, M13, O12, O31, O33, O38 


\section{Introduction}

In a context of increasing international competition and ageing populations, many western governments feel the urge to stimulate innovation in order to secure long term wealth creation. This means that next to the traditional economic criteria of efficiency and equity, innovation is now a more central criterion for economic policy. Innovation is also seen as a tool to move nations through economic crises more quickly and position the nations to have a stronger economy as crises ease. Economic crises may also yield an opportunity to turn destruction into the creative destruction of innovation. Several policy instruments are considered in innovation policy, ranging from investments in public $R \& D$, subsidizing private $R \& D$ and cooperation for innovation, to stimulating entrepreneurship. The latter area is receiving increasing attention in innovation policy. The popularity of a policy instrument is not necessarily an indication of consensus about its effectiveness, or clarity about its content. Entrepreneurship is a fuzzy concept that is used in a confusing way not only in policy, but in academia as well. The same is true for innovation. Nevertheless, there are multiple arguments that innovation is a key mechanism through which entrepreneurs drive economic growth (see for example Audretsch et al. 2006, Baumol 2002, Landes 1998, Rosenberg and Birdzell 1986).

In this chapter we provide a definition of entrepreneurship in the context of innovation, and discuss its role within a cycle of innovation. This cycle of innovation reflects the growth of knowledge in society: innovation is based on the knowledge base of a society and expands this innate knowledge base (cf. Nooteboom 2000; Metcalfe 2002). Increasing the set of future economic choices seems to be a reasonable policy in a context of radical uncertainty (Moreau 2004: 866):

One of the main roles of public policy is indeed to minimise the risks of technological or behavioural lock-in by maintaining some diversity among the characteristics of market participants and thus in the economic trajectories followed. The central policy problem becomes that of increasing the probability and the profitability of experimental behaviour. Thus the attention of the evolutionary policy-maker shifts away from efficiency toward creativity. Nelson and Winter (1982) underline that when the neoclassical hypothesis of a given opportunity set is relaxed, the role of the state becomes to discover and to extend this opportunity set rather than to choose among this set to maximise a hypothetical social welfare function.

Different types of innovation along the cycle of innovation are realized with different forms of entrepreneurship, which are constrained or enabled by different legal institutions. One of the key roles of governments is to design, change or destruct institutions in order to improve societal welfare. Governments typically have the authority to do this. We explicitly take the destruction of institutions into account, because (a) it is often much harder to abolish institutions than to create institutions, and (b) "inefficient economic institutions are the rule, not the exception" (North 1990a: 191). The question is what governments should do in the context of innovation policy. Here, social scientists can make a contribution by providing insight into what entrepreneurship 
and innovation is (theories about these phenomena), and how institutions affect them in reality (empirical evidence about their effects). This requires social scientists to be engaged scholars (cf. Van der Ven 2007) and to provide new policy options as an honest broker between the academic world and the policy world (Pielke 2007). With respect to institutions, the demand for social science knowledge is derived from the demand for institutional change (Ruttan 2006; 2008). Advances in social science could then be useful in policy practice. The key question of this chapter is: How can policy best enable innovation based entrepreneurship? The answer is derived from looking at both theoretical tenets and empirical evidence using an institutional design perspective, which aims at providing arguments for the design, change and/or destruction of institutions, given the goals of the governments. This perspective is closely linked to the new institutional economics (North 1990b; Williamson 2000) and mechanism design theory (Cramton 2008; Myerson 2008; Ruttan 2008).

Traditionally economics principally deals with institutions in a minimal form, e.g. the necessity of institutions that secure property rights for markets to work. New approaches recognize that different institutions are appropriate in different circumstances, and deal with the positive and normative aspects of institutional diversity (cf. Djankov et al. 2003). According to the institutional economic approach to entrepreneurship, the rules of the game (institutions) that specify the relative payoffs to different entrepreneurial activities play a key role in determining whether entrepreneurship is allocated in productive or unproductive ways (Baumol 1990; cf. Murphy et al. 1991).

From a policy perspective the issue at stake is how to design an innovation policy that targets but does not attempt to predetermine the outcomes of industrial development (as was the case with state investment planning in targeted industrial policies). This kind of innovation policy design falls between the targeted industrial policies that are (to some extent) determined by special interest groups on the one extreme, and general economic policies (like fiscal incentives for innovation investments and public investments in education and research) at the other. Targeted industrial policies are a reflection of a belief in the ability to optimally plan the allocation of resources in society. This is at odds with the fundamental uncertain and unpredictable nature of innovation. The latter characteristics do not preclude any role for government however. The role of government is to design institutions that enable the creativity that facilitates innovation, ultimately supporting economic progress (cf. McCloskey 1997). From an institutional design perspective, social science knowledge can play an important role in the rational design of institutional reform and institutional innovation.

This chapter starts with a discussion of the nature of entrepreneurship and its relation to innovation, The next section provides a conceptual elaboration of innovation along a cycle in which exploration and exploration follow upon each other: this goes beyond the Schumpeterian notion of the innovation process that runs from exploration to exploitation only. We place the roles of entrepreneurship in innovation policy within this cycle of innovation. After these conceptual investigations of entrepreneurship and innovation, institutions move centre stage. In this final section we provide an overview of some (empirically tested) institutions that enable or restrain particular types of 
entrepreneurship. Examples of these institutions are intellectual property rights and the Small Business Innovation Research program (for new technology based firms), employment protection (for high-growth start-ups) and non-compete covenants (for spinoffs).

\section{Entrepreneurship and innovation}

What is meant by entrepreneurship and how does it relate to innovation?

Entrepreneurship and innovation are fuzzy concepts with multiple meanings. Innovation and entrepreneurship are often regarded as overlapping concepts. This can be traced back to the definition entrepreneurship put forward by Schumpeter (1934: 74), who defines entrepreneurs as individuals carrying out new combinations (i.e., innovations).

Schumpeter distinguishes four roles in the process of innovation: the inventor, who invents a new idea; the entrepreneur who commercialises this new idea; the capitalist, who provides the financial resources to the entrepreneur (and bears the risk of the innovation project); and the manager, who takes care of the routine day-to-day corporate management. These roles are usually filled by different individuals (see, for example, Kenney,1986). The literature on entrepreneurship recognises a variety of entrepreneurial roles in economic change, all implicitly carrying with them an economically positive connotation. However, if entrepreneurs are defined to be persons who are ingenious and creative in finding ways that add to their own wealth, power, and prestige (Baumol 1990), then it is expected that not all activities will deliver a productive contribution to society (cf. Murphy et al. 1991). There are a variety of other reasons that many entrepreneurs do not directly contribute to an increase in national income: some entrepreneurship is more adequately characterised as a non-profit-seeking activity (cf. Benz 2006). Greater independence and self-fulfilment are more often mentioned as important motivations to become self-employed than increasing earning power (EOS Gallup 2004). Empirical studies show that (on average) entry into self-employment has a negative effect on the monetary income of individuals (Hamilton 2000; Parker 2004). Being an entrepreneur may be rewarding because it entails substantial non-monetary benefits, like greater autonomy, broader skill utilisation, and the possibility to pursue one's own ideas; i.e., more freedom (cf. Sen 1999). These wide ranging effects of entrepreneurship are reflected in the various aims of entrepreneurship policy, ranging from employment growth (lowering unemployment), flexibility of the economy, innovativeness of the economy, individual development, emancipation of females, and integration of ethnic minorities into host societies.

There are dozens of definitions of entrepreneurship (Hebert and Link 1989; Thurik and Van Dijk 1998). There is certainly no one answer to the question of what the phenomenon entrepreneurship 'truly' is. Rather than looking for any essentialist, 'really true' definition of entrepreneurship we prefer to study different forms and functions of entrepreneurship. Taking all entrepreneurship definitions together, they broadly reflect two relatively distinct (but partly overlapping) phenomena (cf. Davidsson 2004). The first of those is the phenomenon that some people, rather than working for somebody else 
under an employment contract, strike out on their own and become self-employed. ${ }^{1}$ This involves some element of innovation at start-up, and some degree of innovativeness is needed to survive. However, innovation is not central to this phenomenon. The second phenomenon involves the development and renewal of any society, market, economy or organisation, which is based on micro-level actors who have the initiative and perseverance to make change happen. Here, 'entrepreneurship' means the creation of new economic activities and organisations ('Schumpeterian entrepreneurship') as well as the transformation of existing ones ('corporate entrepreneurship').

In the context of this chapter we focus on this second phenomenon, 'entrepreneurship'. Some self-employed are innovative but most are not, and it is innovation that we are interested in. In order to narrow down the discussion we propose a working definition of entrepreneurship as 'the introduction of new economic activity by an individual that leads to change in the marketplace' (cf. Davidsson 2004). Change in the market place generally entails new kinds of value for users, or new ways to provide or deliver existing values. This means that we exclude some other interpretations of entrepreneurship (as noninnovative self-employment) and parts of the innovation phenomenon (see figure 1). For example, we exclude non-market activities such as not-for-profit endeavours, changes in contract (e.g., from employee to self-employed) and internal, administrative or organisational changes that do not appreciably affect markets, but include intrapreneurship that is driven by individual action and changes the marketplace. We also exclude mere contemplation of new ideas or introduction of fatally flawed ones that do not change the market (directly or indirectly, via learning mechanisms). We thus do not include novelty and creativity in all domains of human behaviour in our concept of entrepreneurship.

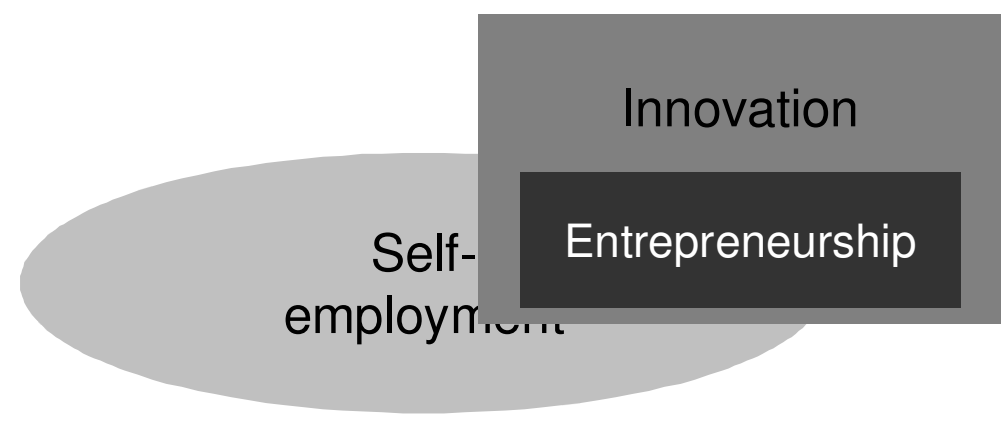

Figure $1 \quad$ Entrepreneurship, innovation, and self-employment

\footnotetext{
${ }^{1}$ In a similar way, entrepreneurship is often equated with self-employment and SMEs in other EU documents (EOS Gallup Europe 2004; European Commission 2006)
} 
Consistent with our definition of entrepreneurship as the introduction of new economic activity by an individual that leads to change in the marketplace, we can formulate several necessary conditions for entrepreneurship (cf. Shane 2003: 6-8):

- existence of entrepreneurial opportunities (environmental changes: technological, political/regulatory, social/demographic);

- difference between people (in their willingness and ability to perceive and act upon an opportunity);

- risk bearing: does demand exist? can the entrepreneur compete with others? can the value chain be created? etc.;

- organising (realising the opportunity); either creating a firm, adapting a firm, or using the market mechanism (for example, licensing);

- innovation: recombination of resources into a new form that is by implication not a perfect imitation of what has been done before, and thus involves a change in the marketplace.

These are necessary conditions for entrepreneurship. However, there are contingencies whether the individuals discovering an opportunity are employees or independent individuals, and whether new firms (spin-offs or independent start-ups) or incumbent firms (acquisitions or corporate venturing) are used for the realisation of the opportunity. We first review the first necessary condition: the existence of entrepreneurial opportunities. $^{2}$

\section{Entrepreneurial opportunities}

Because the range of options and the consequences of exploring new things are unknown, entrepreneurial decisions cannot be made through an optimisation process in which mechanical calculations are made in response to a given set of alternatives (Baumol 1993). People must be able to identify new means-ends relationships that are generated by a given change in order to discover entrepreneurial opportunities. Even if a person possesses the prior information necessary to discover an opportunity, he or she may fail to do so because of an inability to see new means-ends relationships. Unfortunately, visualising these relationships is difficult. History is rife with examples in which inventors failed to see commercial opportunities (new means-ends relationships) that resulted from the invention of important technologies - from the telegraph to the laser.

Every entrepreneur who starts a new business has ideas. The real challenge is to discover an opportunity that is more than just a simple idea. These opportunities can be radical (Schumpeterian) or be incremental (Kirznerian). Entrepreneurial opportunities may originate from changes in the environment. These can be technological, social, demographic, political, or regulatory changes, but also general shocks to the economy (cf. Shane 2003). First, technological change, often based on progress in the research base of society (e.g. biomedical knowledge, or nanotechnology), is a prime source of

\footnotetext{
${ }^{2} \mathrm{We}$ are agnostic on the extent to which these opportunities are to be discovered or created (cf. Sarasvathy et al. 2003).
} 
entrepreneurial opportunities for new technology-based firms. Together social and demographic changes can be quantitative changes like an ageing population that offers new opportunities for entrepreneurs. It may also involve more qualitative changes: changing preferences or wants, for example reflected in the increase in the creative industries that satisfy new wants, or in the trend toward health and nutrition with its resulting demand for the supply of diet and organic food. In that sense people's necessities are few but their wants are endless. Finally, political ad regulatory changes, such as deregulation, privatisation, and liberalisation open up opportunities for entrepreneurship. Examples of privatisation as sources of entrepreneurial opportunities are the outsourcing of municipal services and the privatisation of the health care market, which have provided opportunities for high-growth start-ups.

Until now, we largely left the definition and the discussion about the nature of innovation implicit. We explicitly deal with it in the next section.

\section{Cycle of innovation}

Innovation is about the development of new knowledge, introduced to the economy. This means that it starts with the cognition of the actors involved. This cognition is constructed from interactions of practices (see Nooteboom 2000; 2008). Based on this insight we arrive at an innovation process as a cycle or spiral of idea generation followed by development, commercialisation, market penetration, diffusion, consolidation, and differentiation, which lead to the beginning of invention. Thus this cycle of innovation goes beyond (Neo-)Schumpeterian theory, which includes only the notion of invention as new combinations, and the subsequent commercialization and production (Schumpeter 1934). Where new combinations come from in invention is left unexplained. We see innovation as a cumulative process with discontinuities: today's innovation stands on the shoulders of yesterday's innovation, to paraphrase Merton (1993). Innovation is highly cumulative - building on earlier inventions, development, and applications but also discontinuous in its creative destruction. This nature of innovation - and growth of knowledge more generally - explains why the economy is never in equilibrium (Metcalfe 2002). The cycle of innovation explains how exploitation and exploration succeed each other and emerge from each other (see figure 2 ). ${ }^{3}$

\footnotetext{
${ }^{3}$ Normally a linear approach is taken for explaining processes of innovation, ranging from the linear model of science to innovation (Bush 1945), to innovation diffusion models (Rogers 1962), to more recent innovation chain approaches (Roper et al. 2008).
} 


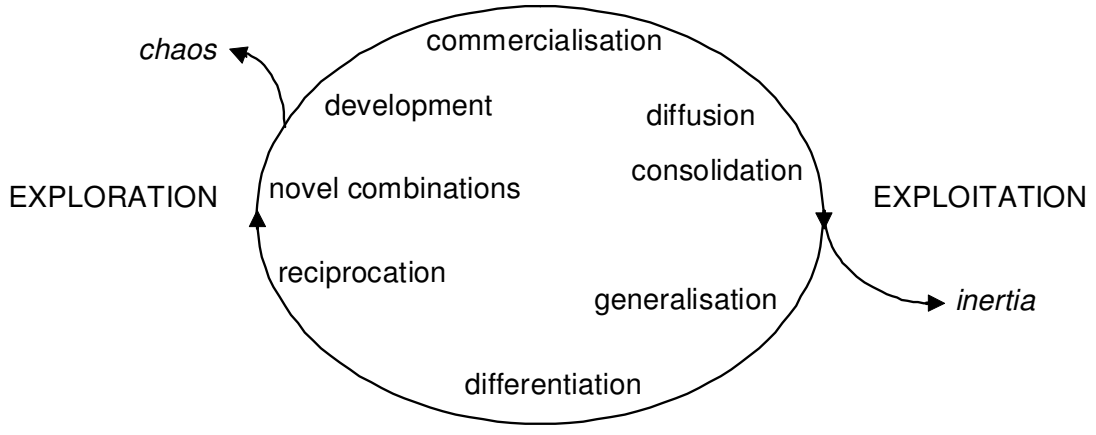

Figure 2 Cycle of innovation

The proposal of a cycle of discovery (Nooteboom 2000) was originally inspired by the work of Piaget on the development of intelligence in children. ${ }^{4}$ Here it is applied the level of firms, products, and technologies within economies. How can such a shift of the level of analysis be justified? The claim here is that the cycle goes beyond empirical phenomena of child development. It represents a more general 'logic' of composition and break-up on the basis of experience, in an alternation of reducing variety of content, in the move toward consolidation (the upper half of figure 2), an opening up of variety of context, in generalisation (the lower half of figure 2), which leads on to a renewed opening of content, in novel combinations. A basic idea of the cycle is that application of existing knowledge and competence in novel contexts (e.g., new applications of theory and technology, new markets for existing products, new jobs for people), called 'generalisation', leads to 'differentiation' of existing practice, for the sake of adaptation to the new selection environment. The new selection environment offers the room to deviate from the previously consolidated institutions that resulted from a previous innovation. In adapting a product or practice to new conditions, one first taps into earlier experience about how things might be done differently, based on experience from earlier rounds of innovation. If differentiation does not suffice in order to survive, or to profit from newly emerging opportunities, a further step is to allow oneself to be inspired by foreign practices encountered in the new environment, which appear successful or promising where one's own practice seems to fail. This leads to experiments with combinations of known elements from existing practice and new elements from unfamiliar, local practices, called 'reciprocation'. This yields hybrid practices. The history of technology offers many examples of the importance of hybrids in the

\footnotetext{
${ }^{4}$ For a survey of Piaget's work, both theoretical and empirical, including criticism, see Flavell (1967).
} 
development of radical innovations (Mokyr 1990). The significance of hybrids is that they allow one to explore the potential of novel elements without immediately surrendering the basic logic, structure, design principles, or architecture of established practice. The problem with hybrids is that they yield inefficiencies and inconsistencies in the system ('spaghetti'), with overlaps, redundancies, misfits, and 'work-arounds' to resolve them. That leads to more radical, architectural change, in Schumpeterian 'novel combinations'. The period of hybridisation gives insight into the elements one would most like to preserve, given their performance in the hybrid, and the directions in which one might think for novel principles of logic or architecture. Here, at this stage, small changes in design principles or basic logic can yield a drastic change in the functioning of the whole. At the same time, the inefficiencies and contradictions of hybrids also form a stumbling block: they may be seen as evidence of failure and lack of perspective for the innovation. Progress then depends on the perseverance of the entrepreneur or inventor. Also, the inefficiencies of reciprocation and hybridisation are difficult to sustain under the pressures of competition. This frequently leads to failure - because problems do indeed prove to be insurmountable or ongoing efforts and uncertainty cannot be sustained - but occasionally it leads to a breakthrough. The cyclical process of innovation indicates how one can set out in exploration along a path of exploitation. Crucial for the process, in the stages of generalisation and reciprocation, is the opening to novel contexts, with new challenges and opportunities, and openness in the form of curiosity and attention to unfamiliar practices and perspectives, and the willingness and opportunity to engage in experiments, and tolerance of the problems with hybrids. The cycle is illustrated in figure 2.

So far, the discussion of the cycle concerns the bottom half, in the transition from exploitation to exploration, which is relatively new in the innovation literature. The top half is more consistent with established innovation theory. Along the top half, in the emergence of a new idea or practice, in a novel combination, there is search for technical feasibility and commercial viability ${ }^{5}$ of a new technology ${ }^{6}$ or product and its optimal configuration, in the emergence of what in the innovation literature is called the 'dominant design' (Utterback 1994; Geroski 2003). This leads to what is labelled

\footnotetext{
${ }^{5}$ Entrepreneurs make conjectures about new combinations that are uncertain - that is, one cannot know (or even calculate the probability) ex ante whether these conjectures will be correct (Knight 1921). Several types of uncertainty can be distinguished: for example technical, market, and competition. The entrepreneur does not know in advance if the good or service she is producing will work, and, if so, if it can be produced at a cost less than the price at which it will be sold (technical uncertainty). The entrepreneur also does not know if demand will exist for the product, and, if so, if customers will adopt in large enough volumes, quickly enough, and at a high enough price, to make the effort profitable (market uncertainty). Finally, the entrepreneur does not know if she will be able to appropriate the profits from the exploitation of the opportunity or if they will dissipate to competitors. This uncertainty will only be resolved with entrance into the market (Rosenberg and Birdzell 1986: 257-258), hence the description of the market as a discovery process.

${ }^{6}$ In contrast to Schumpeter's time, the invention need not to be turned into a product in order to enter the market, since there are now well functioning markets for technology (see Arora et al. 2001). Companies that enter technologies markets do not have to invest in production-related activities but can focus their efforts on building stocks of intellectual property. The choice of entering the product or technology market is highly dependent on the appropriability regime and the extent to which complementary assets are held by existing companies (Teece 1986).
} 
'consolidation'. In that process, if a breakthrough of an innovation succeeds, it faces the need to replace old practices; in Schumpeterian terms, 'creative destruction'. Here, one runs into the problem that existing institutions, in the form of standards and regulations (technical, safety, commercial, fiscal, legal, administrative), market structures (distribution channels, installation, maintenance, repair), schooling and training, as well as established commercial positions, which form the existing selection environment, can block entry and change. In other words, in order to break through, innovation requires institutional change. As a result, due to institutional barriers radical innovations can often break through only later, and initially can only succeed where they can be fitted into the prevailing order of existing institutions and market structures. They need to prove their worth and their potential more extensively before obstacles can be cleared. It is a wellknown phenomenon that innovations initially do not find their application where their potential is highest but where the obstacles are lowest.

Hence, openness of markets for new product entry, with a critical attitude toward established interests and institutions is an issue for innovation policy. One policy implication is that enabling entrepreneurs goes beyond helping them to find their way through the thickets of rules and regulations. It also requires gathering insights as to how obstacles may be changed to accommodate the shifts of innovation.

In the movement toward consolidation, goals, means, and causal relationships between them become clear. As uncertainty decreases and familiarity with the novelty increases among potential users, demand increases, new producers jump into the emerging market, and price competition intensifies. Pressure on price creates pressure toward efficiency, on the basis of process innovation (by large firms: see Falck 2009). For pressures toward efficiency, standard economic analysis applies. Market mechanisms are needed to ensure optimal allocation of scarce resources (allocative efficiency) to known goals and means. In the drive toward efficiency, opportunities are taken to increase productive efficiency, by increase of scale, enabled by growing demand, which leads to concentration and the 'shake-out' of less efficient producers. Here, usually in competition policy, mechanisms are oriented toward removing barriers to entry (see Audretsch et al. 2001).

The fall of profits, in the transition from product innovation to process innovation, during consolidation, yields an argument for trying to be a leader, in the early stage of innovation, because thereby one captures the high profits of early partial monopoly, before imitation sets in (cf. Schumpeter 1942). As a follower, one enters at the stage of consolidation, where users profit from lower prices, but high profits have eroded. Furthermore early leaders may construct entry barriers to followers. As the history of capitalism has shown only an extremely small percentage of all start-ups make it to the position of industry leader (like e.g. Microsoft, Apple, Cisco, and Dell in ICT industries).

Ongoing progress throughout the cycle is by no means guaranteed. The cycle is not to be seen as a logically necessary sequence but as a heuristic that generally works. In trying novel combinations, one may get caught in ongoing uncertainty and chaos (see figure 2), unable to settle the inconsistencies between new goals, means, and connecting causalities. Prototypes may continually fail to become viable, either technically or commercially. 
Rival designs, prototypes, or technical standards may continue to compete for a long time, and for the duration potential users are hesitant to commit themselves. After consolidation, one may get caught in inertia (see figure 2), particularly if there are no opportunities or incentives to escape to new contexts of application, or barriers to novel conditions being imposed from outside. In consolidation, institutions shift to accommodate the innovation, and once that has happened there are often strong pressures toward 'isomorphism' (DiMaggio and Powell 1983), with strong pressures to conform, by 'coercion, mimesis (imitation) or normative pressures'. Vested economic interests protect existing institutions with installed bases of both tangible and intangible investments, existing competencies and efficiencies (accumulated in learning by doing), as well as market positions. Therefore, innovation requires openness to novel contexts of application, e.g., global markets, or new users or suppliers, as arenas for exploration and sources of novel challenges. Stages of the cycle may be skipped, in a leap to novel combinations without much intervening differentiation or reciprocation. The process may not proceed beyond any given stage. For example, differentiation, as a step in exploitation, may not proceed to reciprocation and novel combinations.

Note that progress along the cycle is full of stress and potential conflict. In order to survive in novel contexts, innovators need to adapt their existing practices. In novel combinations innovators encounter stress in trying to have their innovation accepted, and established practices encounter the stress of creative destruction.

The cycle of innovation provides the dynamic basis for the systemic view of innovation and innovation policy, in which innovation policy is concerned with stimulating and matching the knowledge producing elements (exploration) and knowledge exploiting elements (exploitation) of an economy. The cycle of innovation operates, more or less perfectly, depending on institutional conditions that inhibit or enhance the component processes of generalisation (opening up to new contexts); differentiation (deviation from established practice to survive in the new context); reciprocation (opening up to contributions from unfamiliar ideas or practices); experimentation with hybrids and new principles, interpretive schemes or architectures; convergence to a dominant design; and institutional change to accommodate the novelty. Innovation policy is not about the determining the content of innovation, but about enabling innovation processes. Crucial in this policy is the opening to new contexts with new challenges and opportunities, opening to collaboration for the exploration of novel combinations, opening in the form of curiosity and attention to foreign practices, and the preparedness to engage in experiments with elements from those and with surprising hybrids. ${ }^{7}$

\section{Entrepreneurship in the innovation cycle}

It is customary to distinguish between equilibrium breaking, Schumpeterian entrepreneurship that yields 'creative destruction', and 'Kirznerian' entrepreneurship

\footnotetext{
${ }^{7}$ The Renaissance in Europe was accompanied by a lively interest and use of many things that could be found elsewhere (Mokyr 1990). This stands in contrast to China, for example, which from around 1400 lost its prior advantage by closing itself off to foreign influences. Perhaps this helps to explain why the first two industrial revolutions occurred in Europe.
} 
(Kirzner 1973), which finds new market niches for existing or adapted products, in a process of what economists call 'arbitrage,' and thereby tends toward equilibrium. We can recognise this in the cycle of innovation: the movement toward consolidation can perhaps be seen as equilibration, and the movement away from it as disequilibration. Instead of two kinds of entrepreneurship, we can identify a larger range of different types, all along the cycle of innovation. Thus, there are entrepreneurs who make a new idea technically feasible, commercially feasible, productively efficient (e.g. Henry Ford in the automobile industry), eliminate entry barriers, carry it into new markets or applications, differentiate it, bring in new elements, in hybrids, or bring together elements from different practices in new architectures and thereby produce new concepts.

Note that in the step of generalisation the actor who takes an existing product or practice into a new context is not necessarily an existing producer or practitioner. It may be an outside entrepreneur or user stepping in, or an employee spinning off from an existing firm, adopting the product or practice with his own specific experience and perspective. This, however, may already happen prior to consolidation, so that exploration may set in when exploitation has not settled down yet. Entrepreneurs adopting the innovation will inevitably, and not necessarily deliberately, colour their use of it according to their perspective, and seeing that the product is on its way to widespread diffusion and consolidation, with an erosion of profit, may already differentiate it deliberately. What we are saying here is that disequilibration may take place even during equilibration, which seems to make nonsense of the very notion of equilibration. Why would entrepreneurs move toward equilibrium if they know that it will erode profits?

\section{Institutions enabling/constraining entrepreneurship}

The economy would be in chaos without institutions, ${ }^{8}$ one might even argue that economics - production, distribution and consumption - would not exist without institutions. Institutions are the rules that constrain behaviour - and in that way often reduce uncertainty, and transaction costs in particular - and enable (inter)actions. The most basic institutions that enable capitalist economies are property rights and the rule of law. In this paper we focus on how entrepreneurship, specified along the cycle of innovation, is enabled and constrained by institutions. A key question is which (formal) institutions governments should design to enable entrepreneurship, i.e. the introduction of new economic activity by an individual that leads to change in the marketplace. In practice, institutions are often not the product of intentional design, ${ }^{9}$ and are often the outcome of a political process in which the interests of many stakeholders have to be satisfied. However that does not mean that there is no scope for institutional design. ${ }^{10}$

\footnotetext{
${ }^{8}$ Expanding on this: according to Hobbes (1651) society will be in chaos without institutions.

${ }^{9}$ Hayek (1978), for example, held that institutional change emerges out of organic processes, which he termed "spontaneous order".

${ }^{10}$ This very much resembles mechanism design theory that evaluates how the rules that govern exchange and allocation impact the efficiency of alternative (market) institutions (Myerson 2008; Roth 2008).
} 
The relationship between institutions and entrepreneurship seems paradoxical, as the former reduces uncertainty in order to enable behaviour (North 1990b), while the latter involves judgement under uncertainty (Knight 1921; Casson 2003). This paradox is resolved by distinguishing different types of uncertainty (cf. Milliken 1987; Van Waarden 2001). For example, financial institutions are necessary to let financial markets work, so that entrepreneurs can acquire capital for investments with uncertain future returns. The latter uncertainties relate to whether the new product is technically viable, commercially viable, and whether the firm will not be outcompeted by rivals, while the former institutions for example reduce the uncertainties related to the value of money and creditworthiness of firms. Furthermore, institutions may also constrain the making of constraints and enable escape from constraints, creating uncertainty by keeping avenues toward innovation open, as in competition policy, or other elimination of entry barriers, which create the uncertainty of novel entry into markets.

The question of which institutions governments should design to enable entrepreneurship, is not about more or less state or market, since markets require institutions that often only states can construct; it is about how the state can enable entrepreneurs to change the market. This also means that it might have to design institutions that constrain vested interests, or to abolish institutions that serve vested interests, in order to let entrepreneurs flourish.

In order to focus our discussion of how institutions affect entrepreneurship, we will discuss particular types of entrepreneurship that according to the literature have relatively strong positive effects on economic growth: new technology based firms, spin-offs, ${ }^{11}$ and high-growth start-ups. Spin-offs and new technology based firms are likely to be better indicators of exploitation of unused ideas than the general population of new firms, while they may also be involved in the exploration of ideas that have emerged out of the former exploitation of knowledge. High-growth start-ups are even stronger indicators of successful exploitation on a relatively large scale.

\footnotetext{
${ }^{11}$ The focus here is on corporate spin-offs. University spin-offs differ in two important ways. First, noncompete covenants are not a relevant issue for employees in (non competing) public sector organizations. Second, the nature of innovation in university spin-offs mainly involves the upper half of the innovation cycle, i.e. the process from invention to commercialization. Institutional conditions that are important for university spin-offs relate to the incentives for academic entrepreneurship (see Henrekson and Rosenberg 2001), and the provision of seed capital, and lead users (for example via the SBIR program).
} 
Table 1. Types of entrepreneurship and institutions

\begin{tabular}{|l|l|l|l|}
\hline $\begin{array}{l}\text { Type of } \\
\text { entrepreneurship }\end{array}$ & $\begin{array}{l}\text { Position at the } \\
\text { cycle of innovation }\end{array}$ & Institutions & $\begin{array}{l}\text { Enabling / } \\
\text { constraining effects }\end{array}$ \\
\hline $\begin{array}{l}\text { New technology } \\
\text { based firms }\end{array}$ & $\begin{array}{l}\text { Novel } \\
\text { combinations }\end{array}$ & $\begin{array}{l}\text { Intellectual property } \\
\text { rights }\end{array}$ & $\begin{array}{l}\text { Markets for } \\
\text { technology }\end{array}$ \\
\hline $\begin{array}{l}\text { New technology } \\
\text { based firms }\end{array}$ & $\begin{array}{l}\text { Novel } \\
\text { combinations- } \\
\text { development- } \\
\text { commercialization }\end{array}$ & $\begin{array}{l}\text { Small Business } \\
\text { Innovation Research } \\
\text { (SBIR) program }\end{array}$ & $\begin{array}{l}\text { Sourcing of radical } \\
\text { small firms } \\
\text { innovations; } \\
\text { commercialisation of } \\
\text { public research }\end{array}$ \\
\hline Spin-off firms & $\begin{array}{l}\text { Generalization, } \\
\text { differentiation }\end{array}$ & $\begin{array}{l}\text { Non compete } \\
\text { covenants (labour } \\
\text { market) }\end{array}$ & Exploitation of ideas \\
\hline $\begin{array}{l}\text { High-growth } \\
\text { start-ups }\end{array}$ & $\begin{array}{l}\text { Commercialization- } \\
\text { generalization }\end{array}$ & $\begin{array}{l}\text { Employment } \\
\text { protection (labour } \\
\text { market) }\end{array}$ & $\begin{array}{l}\text { Reallocation of } \\
\text { labour }\end{array}$ \\
\hline
\end{tabular}

New technology based firms and patents

Entrepreneurs wanting to develop new technologies and introduce them to the market face Arrow's disclosure problem (Arrow 1962): the value of a new technology to any one buyer may be decreasing in the number of other potential buyers who have been able to evaluate the new technology due to information leakages in the valuation process (value rivalry). There is thus a risk of expropriation the 'rights' to use this new technology of the inventor if this invention has not been registered and protected by patent rights. The enforcement of patents or licensing agreements acts as an entry barrier that significantly reduces the potential for user reproducibility. Patent rights explicitly prevent would-be buyers from using the idea for commercial gain without the permission of the technology seller. The legal institution that solved this disclosure problem is the protection of intellectual property rights via patents (see Gans and Stern 2010). New firms that specialize in the development of new technologies can thus claim the property rights of the inventions involved and gain from trading the use rights of this invention with licensing on a market for technology (cf. Arora et al. 2001). The availability of intellectual property protection by patents has been instrumental in the rise of the number of new firms in knowledge intensive sectors like biotech and R\&D services. ${ }^{12}$

\section{New technology based firms and SBIR}

The Small Business Innovation Research (SBIR) program is a public procurement programme aimed to subcontract socially relevant (i.e. fulfilling a public need) innovative research to small businesses. The program's central goals are (1) meeting federal research needs with small business and (2) fostering commercialization of federally funded research (Cooper 2003). The US Congress enacted the SBIR program in

\footnotetext{
${ }^{12}$ However, there is increasing evidence on the malfunctioning of the (US) patent system: see Jaffe and Lerner (2004), Bessen and Meurer (2008).
} 
the early 1980s as a response to the loss of American competitiveness in global markets, especially in the face of the 'Japanese threat' (see Audretsch 2003). The birth of the SBIR program was the result of lobbying activities by the National Science Foundation (NSF) and the Small Business Administration (SBA) (Obermayer 2009). There was no clear design, but the program was constructed and evolved through a trial-and-error process taking into account both the political and administrative viability of the program. The US regulation underpinning the SBIR programme requires that $2.5 \%$ of all federal government agency external R\&D budgets are distributed to small innovative businesses. Each year the SBIR program makes more than 4,000 awards to US small businesses, amounting to over $\$ 2$ billion in value (Connell 2006). The SBIR consists of three phases: feasibility, development and commercialization. Phase I is oriented toward determining the scientific and technical merit (technological creativity) along with the feasibility (economic creativity) of a proposed research idea. A Phase I award (typically around $\$ 100,000)$ provides an opportunity for a small business to establish the feasibility and technical merit of a proposed innovation. This is a step generally ignored by private venture capital. Phase II awards are more selectively aimed at developing new technologies and products, which involves about $50 \%$ of the phase I award winners, and delivers up to $\$ 750,000$. Phase III awards are funded from mainstream (i.e., non SBIR budgets), and add probably again as much as Phase I and II in total to overall R\&D expenditure on SBIR projects (Connell 2006). These Phase III projects also bring small businesses the opportunity to win valuable sole supplier contracts with federal agencies. Some of the most innovative American companies, like Genzyme, Amgen, and Genentech—all three university spin-offs_-as well as Apple Computer, Compaq, Intel and Qualcomm received early stage SBIR finance. Lerner (1999) shows that SBIR funded firms enjoyed substantially greater employment and sales growth than other similar firms. It is not just the size of the subsidy that is important for the recipients: these awards also play an important certification function, increasing the trustworthiness of the recipients (Lerner 1999; cf. Toole and Turvey 2009). This implies that the program's project review and selection process identifies the quality of projects and firms, so that information asymmetries are reduced that normally are an important cause of the failure of financial markets to provide investment capital to these projects and firms.

From an innovation policy point of view, the SBIR program has the general purpose of stimulating technological innovation, and the more specific purpose to tap into the pool of innovative potential of small businesses to meet federal R\&D needs on the one hand, and to increase private sector commercialization of inventions derived from federal R\&D: i.e. to stimulate novel combinations, technology development and commercialization in the innovation cycle. The evolutionary design of the program facilitates maximum experimentation, with minimal financial losses per experiment. The program also reduces the inherent uncertainty involved in technological innovation concerning the functionality of the technology, the ability to produce new technology based products, and the demand for the new product. In combination with providing 'venture capital' for product development, the SBIR program reduces multiple barriers to technological innovation that are said to be especially harmful for new and small technology based firms (cf. Hall 2002). 
The program reduces the typical large firm bias in public procurement. Public procurement in general, and innovation procurement in particular, favours large firms for logical reasons: due to accountability of these larger and often long established parties, and the relatively low transaction costs for government procurement to a small set of large established firms. Procurement to a large set of small and new firms incurs more search costs, contract costs, and control costs. This problem is even more severe when the 'product' subcontracted involves high uncertainties and many intangible assets, as is the case with subcontracting of innovative research. However, the downside of subcontracting to large established firms is that relatively incremental innovations will be sourced, due to the small variety of potential innovations, and the relative inert nature of larger long established firms. The problem then is how to source more radical forms of innovation, and solving the two (capital and product) market problems for new tech based firms. The SBIR program turned out to be an institutional change that solved these problems.

\section{Spin-offs and non-compete agreements}

Spin-off firms are a specific form of employee mobility, in which employees leave their former employer to pursue opportunities in their newly created and owner-managed legal entity. These entrepreneurs introduce ideas from their prior work experience to new contexts (generalization), and sometimes substantially differentiate these ideas in order to adapt to new selection environments (differentiation).

A number of studies show that one particular legal constraint on employee mobility employee non-compete agreements ${ }^{13}$ - lowers the ability of employees to move from one firm to another (Gilson 1999; Fallick et al. 2006; Marx et al. 2009). These employee noncompete agreements are intended to help firms protect their investments in human capital, intellectual property ${ }^{14}$ and relationships: firms can increase their productivity by training their workers, by developing new products and processes, as well as by building valuable relationships with customers and suppliers (see Franco and Mitchell 2008). These non-compete agreements may also reflect the vested interests of incumbents that want to restrict the possibility of employees striking out on their own, and exploiting their knowledge outside the former employer. In this respect employee non-compete agreements may be a constraint on the creation of spin-off firms, which has been confirmed by several studies (Stuart and Sorenson 2003; Samila and Sorenson 2009).

\section{High-growth start-ups and employment protection}

Labour market regulations leading to large hiring and firing costs are negatively associated with new firm formation (Van Stel et al., 2007). This finding might reflect different mechanisms: relatively high opportunity costs for employees to become self-

\footnotetext{
${ }^{13}$ The fact that this is a non-compete agreement, means that this institution is of less relevance in noncompetitive settings of public research institutes and their potential spin-offs.

${ }^{14}$ Marx et al. (2009) showed that patents (the regular legal protection of inventions) and non-compete agreements are complements, not substitutes. Both are legal institutions to control knowledge, either embodied knowledge (non-compete agreements) or codified knowledge (patents).
} 
employed, constraints on the flexibility of highly uncertain innovative start-ups, or potential problems with attracting personnel for a growing new venture. There is some empirical evidence for all three mechanisms: Robson (2003) found that stricter employment protection legislation in OECD countries reduces self-employment; ${ }^{15}$ Bosma et al. (2009b) found that the probability of individuals in European countries to start an innovative firm is negatively related to the strictness of employment protection, and Bosma et al. (2009a) found the same relation for the probability to start a new firm with high growth expectations. See Henrekson and Johansson (2009) for an extensive discussion of the effects of labour market institutions on the prevalence of high-growth firms.

An overview of the reviewed institutions and their place along the innovation cycle is shown in figure 3.

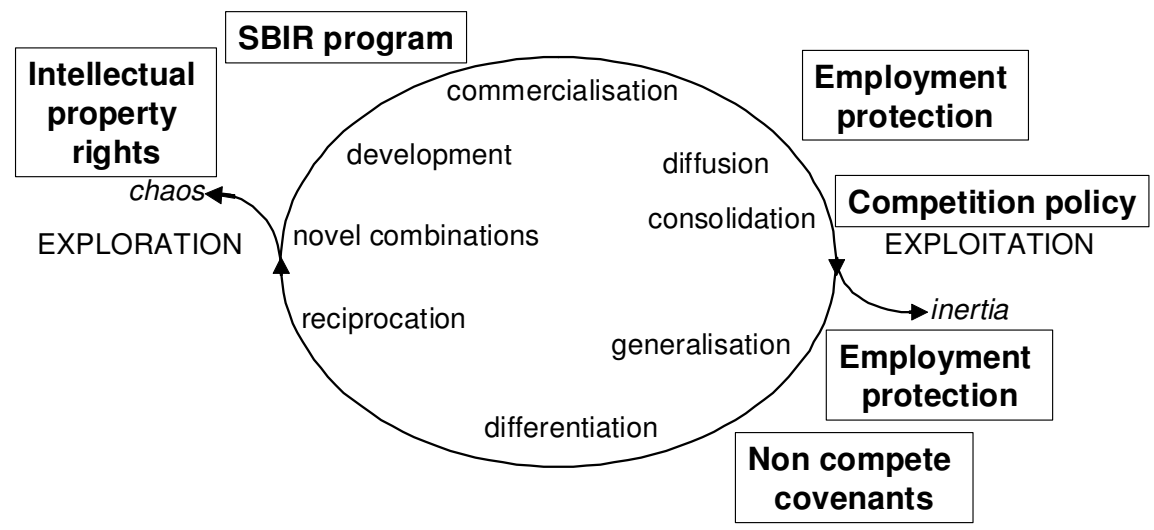

Figure 3 Institutions along the cycle of innovation

\section{Conclusions}

In this chapter we provide a definition of entrepreneurship in the context of innovation, and discuss its role in a cycle of innovation. This cycle of innovation reflects the growth of knowledge in society: innovation is based on the knowledge base of a society and expands this knowledge base. Different types of innovation along the cycle of innovation are realized with different forms of entrepreneurship, which are constrained or enabled by different institutions. One of the key roles of governments is to design, change or destruct

\footnotetext{
${ }^{15}$ This is not that obvious, as the reverse might also be logical: strict employment protection legislation may promote self-employment by encouraging employers to contract-out work to self-employed workers.
} 
institutions in order to improve welfare in society. The key question of this chapter is: How can policy best enable innovation based entrepreneurship? We take an institutional design perspective, which aims at providing arguments for the design, change and/or destruction of institutions, given the goals of government. This is illustrated by how four different formal institutions enable or constrain different types of entrepreneurship through the innovation cycle. These illustrations also show that it is unfruitful to see these institutions as either designed or as evolving spontaneously: the selection and consequential design and creation of institutions is both intended and unintended, which means that institutional learning becomes crucial.

The translation of scientific insights into the world of policy practice has several caveats. First, the success of institutional design in the context of innovation policy remains uncertain due to unforeseen interdependencies and unintended side-effects. Bringing the nuances and contingencies in the effects of institutional change centre stage might constrain the adoption of these insights into the world of policy practice. However this should not be a ticket to the exclusive use of slogans and sound bites in the policy debate. The message should be simple enough to be communicated to broad non-scientific audience, but should have enough causal depth and contextual sensitivity in order to avoid harmful translations of academic insight.

The second caveat concerns the dangers of evidence based policy. Evidence based in social sciences means building on academic publications in social science fields. In contrast to for example the medicine field of research, replication research is not greatly valued in social sciences (cf. Davidsson 2004, chapter 9; Evanschitzky et al. 2007). There is a tendency to publish success studies thus undersampling failures or zero-effect outcomes (cf. Denrell 2003). This means that the social science knowledge base on the effects of institutions on entrepreneurship and innovation more broadly is not likely to be an unbiased pool of insights for the design of institutions. In order to become a reliable pool of insights, social sciences should become more like the medical sciences and emphasize replication studies (over time and different contexts) and to engage as scholars with the actors involved in order to uncover the ways in which institutions affects their behaviour (cf. Van de Ven 2007).

\section{References}

Arora, A., Fosfuri, A. and Gambardella, A. (2001) Markets for technology and their implications for corporate strategy. Industrial and Corporate Change 10: 419 451.

Arrow, K. (1962) Economic welfare and the allocation of resources for invention. in: The Rate and Direction of Inventive Activity: Economic and Social Factors, Princeton University Press, Princeton, NJ. pp. 609-625.

Audretsch, D.B. (2003) Standing on the Shoulders of Midgets: The U.S. Small Business Innovation Research Program (SBIR). Small Business Economics 20: 129-135.

Audretsch, D.B., Baumol, W.J. and Burke, A.E. (2001) Competition policy in dynamic markets. International Journal of Industrial Organization 19: 613-634. 
Audretsch, D.B., M.C. Keilbach, and E.E. Lehmann (2006) Entrepreneurship and Economic Growth. Oxford University Press: Oxford.

Baumol, W.J. (1990) Entrepreneurship: Productive, Unproductive, and Destructive. Journal of Political Economy 98(5): 893-921.

Baumol, W. (1993) Formal Entrepreneurship Theory in Economics: Existence and Bounds. Journal of Business Venturing 8: 197-210.

Baumol, W.J. (2002) The Free-Market Innovation Machine - Analyzing the Growth Miracle of Capitalism. Princeton University Press: Princeton.

Benz, M. (2006) Entrepreneurship as a Non-profit-seeking Activity. Institute for Empirical Research in Economics Working Paper \#243, University of Zurich.

Bessen, J. and Meurer, M.J. (2008) Patent failure: how judges, bureaucrats, and lawyers put innovators at risk. Princeton University Press: Princeton (NJ).

Bosma, N., Schutjens, V. and Stam, E. (2009a) Two faces of Entrepreneurship. Drivers of innovative and replicative entrepreneurship. Paper presented at the DIME workshop "Regional Entrepreneurship as a source of Perpetuation and Change" October 15-17, Jena.

Bosma N., Schutjens, V. and Stam, E. (2009b) Entrepreneurship in European Regions: Implications for Public Policy. In: Leitao, J. and Baptista, R. (eds) Public Policies for Fostering Entrepreneurship: A European Perspective. Springer: New York. pp. 59-89.

Bush, V. (1945) Science The Endless Frontier. United States Government Printing Office, Washington ( http://www.nsf.gov/about/history/vbush1945.htm ).

Casson, M.C. (2003) The Entrepreneur: An Economic Theory. (2 ${ }^{\text {nd }}$ edition) Edward Elgar: Cheltenham.

Connell, D. (2006) 'Secrets' of the World's Largest Seed Capital Fund: How the United States Government Uses its Small Business Innovation Research (SBIR) Programme and Procurement Budgets to Support Small Technology Firms. Centre for Business Research, University of Cambridge: Cambridge, UK.

Cooper, R.S. (2003) Purpose and Performance of the Small Business Innovation Research (SBIR) Program. Small Business Economics 20: 137-151.

Cramton, P. (2008) Innovation and Market Design. In: Lerner, J. and Stern, S. (eds) Innovation Policy and the Economy. Chicago: National Bureau of Economic Research. pp. 113-137.

Davidsson, P. (2004) Researching Entrepreneurship. Springer: New York.

Denrell, J. (2003) Vicarious Learning, Undersampling of Failure, and the Myths of Management. Organization Science 14(3): 227-243.

DiMaggio, P.J. and Powell, W.W. (1983) The iron cage revisited: Institutional isomorphism and collective rationality in organizational fields. American Sociological Review 48: 147-160.

Djankov, S., Glaeser, E., La Porta, R., Lopez-de-Silanes, F., and Shleifer, A. (2003) The new comparative economics. Journal of Comparative Economics 31: 595-619.

EOS Gallup (2004) 'Flash 160 “Entrepreneurship"', survey for Directorate General Enterprise - European Commission. Brussels: EOS Gallup.

European Commission (2006) Report on the implementation of the Entrepreneurship Action Plan, Brussels: European Commission - DG Enterprise and Industry. 
Evanschitzky, H., Baumgarth, C., Hubbard, R. and Armstrong, J.S. (2007) Replication research's disturbing trend. Journal of Business Research 60: 411-415.

Falck, O. (2009) Routinization of innovation in German manufacturing: the DavidGoliath symbiosis revisited. Industrial and Corporate Change 18(3): 497-506.

Fallick, B., Fleischman, C.A. and Rebitzer J.B. (2006) Job-hopping in Silicon Valley: Some Evidence Concerning the Microfoundations of a High-technology Cluster. Review of Economics and Statistics 88:472-481.

Flavell, J.H. (1967) The developmental psychology of Jean Piaget. Van Nostrand: Princeton, NJ.

Franco, A.M. and Mitchell, M.F. (2008) Covenants not to Compete, Labor Mobility, and Industry Dynamics. Journal of Economics and Management Strategy 17:581-606.

Gans, J.S. and S. Stern (2010) Is there a market for ideas? Industrial and Corporate Change 19(3): 805-837.

Geroski, P. (2003) The Evolution of New Markets. Oxford University Press: Oxford.

Gilson, R.J. (1999) The Legal Infrastructure of High Technology Industrial Districts: Silicon Valley, Route 128, and Covenants Not to Compete. New York University Law Review 74: 575-629.

Hall, B. (2002) The Financing of Research and Development. Oxford Review of Economic Policy 18: 35-51.

Hamilton, B.H. (2000) Does Entrepreneurship Pay? An Empirical Analysis of the Returns to Self-employment. Journal of Political Economy 108: 604-631.

Hayek, F. (1978) New Studies in Philosophy, Politics, Economics, and the History of Ideas. Routledge and Kegan Paul: London.

Hebert, R.F. and Link, A.N. (1989) In Search of the Meaning of Entrepreneurship. Small Business Economics 1(1): 39-49.

Henrekson, M. and Johansson, D. (2009) Competencies and Institutions Fostering Highgrowth Firms. Foundations and Trends ${ }^{\circledR}$ in Entrepreneurship 5(1): 1-80.

Henrekson, M. and Rosenberg, N. (2001) Designing Efficient Institutions for ScienceBased Entrepreneurship: Lesson from the US and Sweden. Journal of Technology Transfer 26(3): 207-231.

Hobbes, T. (1651) Leviathan (reprint 1968). Penguin: Harmondsworth.

Jaffe, A.B. and Lerner, J. (2004) Innovation and Its Discontents: How Our Broken Patent System is Endangering Innovation and Progress, and What to Do About It. Princeton University Press: Princeton (NJ).

Kenney, M. (1986) Schumpeterian Innovation and Entrepreneurs in Capitalism: A Case Study of the US Biotechnology Industry. Research Policy 15: 21-31.

Kirzner, I.M. (1973) Competition and Entrepreneurship. University of Chicago Press: Chigago.

Knight, F. H. (1921) Risk, Uncertainty and Profit. Hart, Schaffner \& Marx: Boston, MA.

Landes, D.S. (1998) The Wealth and Poverty of Nations: Why Some Are So Rich and Some So Poor. W.W. Norton: New York.

Lerner, J. (1999) The Government as Venture Capitalist: The Long-run Effects of the SBIR Program. Journal of Business 72(3): 285-297.

Marx, M., Strumsky, D. and Fleming, L. (2009) Mobility, Skills, and the Michigan Noncompete Experiment. Management Science 55(6): 875-889. 
McCloskey, D. (1997) The Vices of Economists; The Virtues of the Bourgeoisie. Amsterdam University Press: Amsterdam.

Merton, R.K. (1993) On the Shoulders of Giants. University of Chicago Press: Chicago, IL.

Metcalfe, J.S. (2002) Knowledge of growth and the growth of knowledge. Journal of Evolutionary Economics 12(1): 3-15.

Milliken, F. (1987) Three types of perceived uncertainty about the environment: state, effect, and response uncertainty. Academy of Management Review 12(1): 133-143.

Mokyr, J. (1990) The Lever of Riches: Technological Creativity and Economic Progress. Oxford University Press: Oxford.

Moreau, F. (2004) The role of the state in evolutionary economics. Cambridge Journal of Economics 28: 847-874.

Myerson, R.B. (2008) Perspectives on Mechanism Design in Economic Theory. American Economic Review 98(3): 586-603.

Murphy, K.M., A. Schleifer, and R.W. Vishny (1991) The Allocation of Talent: Implications for Growth. Quarterly Journal of Economics 106 (2): 503-30.

Nelson, R.R. and Winter, S. (1982) An Evolutionary Theory of Economic Change. Cambridge, MA: Belknap Press.

Nooteboom, B. (2000) Learning and Innovation in Organizations and Economies. Oxford University Press: Oxford.

Nooteboom, B. (2008) Learning, Discovery, and Collaboration. in: Nooteboom, B. and Stam, E. (eds) Micro-foundations for Innovation Policy. Amsterdam University Press: Amsterdam. pp. 75-102.

North, D.C. (1990a) Institutions and a transaction-cost theory of exchange. In: Alt, J.E. and Shepsle, K.A. (eds) Perspectives on positive political economy. Cambridge University Press: New York. pp. 182-194.

North, D.C. (1990b) Institutions, Institutional Change and Economic Performance. Cambridge University Press: Cambridge.

Obermayer, A.S. (2009) The Role of Senator Ted Kennedy in the Birth of the Small Business Innovation Research Program. Mimeo.

Parker, S.C. (2004) The Economics of Self-employment and Entrepreneurship. Cambridge University Press: Cambridge.

Pielke, R. (2007) The Honest Broker: Making Sense of Science in Policy and Politics. Cambridge University Press: Cambridge.

Robson, M.T. (2003) Does stricter employment protection legislation promote selfemployment? Small Business Economics 21(3): 309-319.

Rogers, E.M. (1962) Diffusion of innovations. Free Press: New York.

Roper, S., Du, J. and Love, J.H. (2008) Modelling the innovation value chain. Research Policy 37: 961-977.

Rosenberg, N. and L. Birdzell (1986) How the West Grew Rich. Basic Books: New York.

Roth, A. E. (2008) What Have We Learned from Market Design? Economic Journal 118: $285-310$.

Ruttan, V.W. (2006) Social science knowledge and induced institutional innovation: an institutional design perspective. Journal of Institutional Economics 2(3): 249-272. 
Ruttan, V.W. (2008) Induced technical change, induced institutional change and mechanism design. Staff Paper P08-1 Department of Applied Economics, University of Minnesota.

Samila, S., and Sorenson, O. (2009) Non-compete covenants: Incentives to innovate or impediments to growth. SSRN working paper 1411172

Sarasvathy, S. D., Dew, N. Velamuri, S. R. and Venkatamaran, S. (2003) Three Views of Entrepreneurial Opportunity. in: Acs, Z. J. and Audretsch, D. B. (eds) Handbook of Entrepreneurship Research. Boston: Kluwer. pp. 141-160.

Schumpeter, J.A. (1934) The Theory of Economic Development. Harvard University Press: Cambridge MA.

Schumpeter, J. A. (1942) Capitalism, Socialism, and Democracy. Harper and Brothers: New York.

Sen, A. (1999) Development as Freedom. Oxford University Press: Oxford.

Shane, S. (2003) A General Theory of Entrepreneurship: The Individual-Opportunity Nexus. Edward Elgar: Cheltenham.

Stuart, T.E. and Sorenson, O. (2003) Liquidity Events and the Geographic Distribution of Organizational Foundings. Administrative Science Quarterly 48:175-201.

Teece, D. (1986). Profiting from technological innovations: implications for integration, collaboration, licensing and public policy. Research Policy 15: 285 - 305

Thurik, A.R. and B. Van Dijk (1998) Entrepreneurship: visies en benaderingen. in: Scherjon, D.P. and Thurik, A.R. (eds.) Handboek ondernemers en adviseurs in het MKB. Kluwer Bedrijfsinformatie: Dordrecht. pp. 127-147.

Toole, A.A. and Czarnitzki, D. (2007) Biomedical academic entrepreneurship through the SBIR program. Journal of Economic Behavior and Organization 63: 716-738.

Toole, A.A. and Turvey, C. (2009) How does initial public financing influence private incentives for follow-on investment in early-stage technologies? Journal of Technology Transfer 34: 43-58.

Utterback, J. (1994) Mastering the dynamics of innovation. Boston: Harvard Business School Press.

Van de Ven, A. (2007) Engaged Scholarship. Oxford University Press: New York.

Van Stel A., Storey, D. and Thurik, A.R. (2007) The Effect of Business Regulations on Nascent and Young Business Entrepreneurship. Small Business Economics 28(2): 171-186.

Van Waarden, F. (2001) Institutions and Innovation: The Legal Environment of Innovating Firms. Organization Studies 22(5): 765-795.

Williamson, O.E. (2000) The New Institutional Economics: Taking Stock, Looking Ahead. Journal of Economic Literature 38(3): 595-613. 